\title{
UMJETNOST KAO TERAPIJA
}

\section{SAŽETAK}

Reformom školstva $i$ prelaskom osnovnog obrazovanja $u$ devetogodišnje osnovno obrazovanje, po prvi se put u proces nastave uključuju i djeca s posebnim potrebama.

Još mnogo više $i$ mnogo prije nego u općem obrazovanju $u$ likovnom odgoju i obrazovanju se postavljaju brojni odgojni ciljevi, koji obuhvataju široki raspon od poticaja psihomotornog razvitka pa do estetske osjetljivosti i njezina emocionalnog korelata.'

Već nekoliko godina terapeutska zajednica kao oblik liječenja $i$ druženja djeluje na Odjelu neuropsihijatrije Kantonalne bolnice „Dr. Irfan Ljubijankić", kao i održavanje umjetničke radionice i izložbe pod nazivom „Bojom $i$ riječima iz srca $i$ duše“. Pacijentima je omogućeno da kroz umjetničko djelovanje dopru do bržeg ozdravljenja, ostavljajući iza sebe zanimljiva likovna i literarna djela.

Budući da su pacijenti naslikali veliki broj slika, Odjel neuropsihijatrije je u saradnji Muzeja USK-a, organizirao izložbu pacijenata terapeutske radionice „Bojom riječima iz srca $i$ duše“. Prema riječima $d r$. Elvira Selimbegovića, načelnika odjela neuropsihijatrije: „Cilj izložbe je da se pacijenti osim procesa liječenja uz stručne ljude i medicinsko osoblje okrenu široj društvenoj zajednici u cilju lakše resocijalizacije. "

Druga grupu čine djeca sa posebnim potrebama. Udruženje roditelja, djece $i$ omladine $s$ posebnim potrebama ,u sklopu svojih programskih aktivnosti sve češće organizuju umjetničke radionice" art terapije na kojima se djeca kroz metode igre uspijevaju spontano $i$ slučajno likovno izraziti. Koordinacija oka i ruke poneku tehniku škropi, a zatim prskanje ili oblikovanje boja i forme, zapravo pokazuje da su djeca puna volje i mašte.

Emocije i crtanje

Emocija nas vodi i potiče na aktivnost. Motivacija učenika može se postici aktiviranjem pozitivnih emocija. Emocije, uzbuđenje, 
osjećajnost, ljubav i estetska osjećanja, gotovo su uvijek prisutni u dječjem likovnome stvaralaštvu. Odsutnost pozitivnih emocija izaziva opadanje intenzivnosti rada, ritma za krvotok, disanja, endokrinog sistema. U nastavi se često zaboravljaju emocije. To najviše ovisi o nastavniku i njegovoj sposobnosti aktiviranja učenika a ponekad i od samoga raspoloženja učenika. ${ }^{1}$

Želja mi je skrenuti pažnju na značaj umjetnosti u liječenju duševnih bolesti i sve veću potrebu u afirmaciji kreativnosti.

Ključne riječi: Aktiviranje, art terapija, elementi, fenomenologija, igra, izražavanje, kreativnost, mašta, metoda, obrazovanje, princip socijalizacije, razvoj, slikanje, spontano, stvaralaštvo, usmjeravanje.

\section{Uvod}

Art terapija kroz likovni izraz djece

Karakteristika umjetničkog dječjeg izražavanja, jeste jedinstveni lični pristup koji u sebi sadrži različite elemente svjesnog i nesvjesnog značenja reprezentativnih za mnoge vidove djeteta koje ih je stvorilo. Većina terapeuta koji rade $\mathrm{s}$ djecom smatraju crtež efektivnim terapeutskim pristupom, jer pomaže djeci u izražavanju na načine koje jezik ne omogućuje. Oni tada koriste likovni jezik.

Početkom XX stoljeća pojavljuje se interes u psihijatriji, psihologiji i obrazovanju za simbole koji se pojavljuju u umjetnosti, što je potaknulo razvoj neovisnog područja umjetnosti kao art terapija. Umjetnička ili art terapija je upotreba slikarskih, vajarskih i drugih kreativnih formi izražavanja $u$ tretmanu osoba sa emocionalnim problemima. Art terapija se često koristi kod liječenja pacijenata mentalno narušenog zdravlja i trauma, no smatra se kako je efektivna i kod zdravih ljudi koji žele podijeliti svijet kreativne sklonosti kao sredstvo poboljšanja ličnoga rasta i razvoja.

To je jedan od psiho terapeutskih pristupa, čija je osobitost $u$ tome što primjenjuje stvaralački likovni proces kao sredstvo izražavanja i komunikacije; znači da klijent kroz crtež, sliku ili

\footnotetext{
${ }^{1}$ Vidi: V. Bodulić, Umjetnički i dječiji crtež, Školska knjiga, Zagreb, 1982., str. 48. 
skulpturu pokazuje svoje misli, osjećaje, imaginaciju, koje uglavnom ne može izraziti u razgovoru.

Crtež tako često iznenadi osobu koja ga je nacrtala, jer na površinu iznosi teme kojih dotada nije bila svjesna. Razgovor često uspijeva sakriti prave misli i osjećaje pa i od nas samih, jer smo dobro naučeni govoriti ono što je dopušteno, očekivano i u skladu $s$ vlastitom slikom o nama. Duboko potisnute ostaju želje , povrjede, ljutnja, snovi - pravi osjećaji koji nas čine osobama kakve jesmo. Tek kada ih osoba postane svjesna, ima mogućnost razumijevanja i mijenjanja.

Da bi se situacija mogla bolje sagledati, treba joj pristupiti sa što više aspekata. U tu svrhu se psihoterapija služi različitim kreativnim metodama, kao što je izražavanje kroz crtež, glazbu, pokret ili dramu. Odrasle osobe često kažu kako ne znaju crtati, pjevati, plesati ili glumiti.

No, treba istaknuti da se kreativna art terapija koristi $\mathrm{s}$ metodama psihoterapije i kao podsticaj za samoizražavanjem, izbacivanjem negativnih emocija, potičući samostalnost, kreativnost i odlučnost. Bez obzira da li je čovjek sklon slikanju, pjevanju, sviranju, modeliranju, pisanju ili nekoj drugoj kreativnosti, svaka aktivnost potiče pozitivna razmišljanja, ulijeva nadu i volju za komunikacijom među ljudima.

Art terapija može početi razgovorom ili crtanjem. Ako umjetnik-terapeut smatra da bi sugeriranje teme ili tehnike pomoglo i brže dovelo do pozitivnoga razvoja procesa, on će sugerirati slobodnu temu ili temu koja je bliska i draga pacijentu. Važno je da u terapiji postoji atmosfera opuštenosti i slobode izražavanja. Art terapija se primjenjuje onoliko dugo, koliko se to smatra korisnim za klijenta.

Art terapija se najviše primjenjuje principom socijalizacije, to jest u velikim grupama, kao i s osobama specifičnih problema i onima koji žele razviti ličnu kreativnost.

Također se koristi u specijalnim područjima kao što je rad sa djecom s posebnim potrebama, ožalošćenim osobama, ovisnicima o drogi, alkoholu, porodicama, psihijatarskim bolesnicima itd. 
Umjetnost, kao vrhunski duhovni izraz čovjeka, pomaže nam u boljem razumijevanju prirode koja nas okružuje, njenih tajni i ljepota, pomaže nam u izgrađivanju novih vrijednosti i moralnih kvaliteta. Umjetnost u službi terapije njeguje zapostavljene osjećajne kvalitete čovjeka, njegove duševne snage, srce, snagu volje i želju za razvoj djeteta. Boje i harmonični oblici su hrana za dušu djeteta koja razvija ljepotu, dobrotu, moralnost i zdrave socijalne odnose.

Umjetnost je u svim kulturama imala poseban značaj. Civilizacije su prolazile, ostavljale tragove svoga življenja, svoje kulture, običaje, vjere, a umjetnost je kulturno vodila i odgajala čovječanstvo: bojama, muzikom, plesom, riječju, knjigom, uspješno se primjenjivala i u liječenju. Vremenom je ovaj značaj umjetnosti bio zanemaren sve do općeg porasta svijesti kada dobiva sve veću pažnju.

Naročito se uviđa njena ljekovitost $u$ tretmanima, tako da $\mathrm{u}$ svijetu danas postoji niz klinika i terapeutskih centara koji primjenjuju umjetnosti u terapijske svrhe, kao sastavni dio sveukupnog tretmana liječenja.

\section{Metoda igre}

$\mathrm{U}$ radu s djecom art terapija ima veliku prednost $\mathrm{u}$ odnosu na verbalnu psihoterapiju.

Za djecu je crtanje, igra spontana i zabavna aktivnost. Dječiji crteži su ekspresivni i direktni. Kroz njih djeca komuniciraju, te su oni odraz dječje mašte.

\section{Slikanje prstima i nogama}

I slikanje ima terapeutsku vrijednost. Kako teče slikanje tako teku i emocije. Većina djece vole slikati, vole baratati bojama i upotrebljavati ih. Nastavnik djeci može sugerirati bilo šta i čekati ishod. Obično se ton, boja i samo slikanje slažu sa emocijama djeteta. Mala djeca vole slikati bez instrukcija. Ona se jako zaposle posipanjem i miješanjem boja a kasnije vam opišu šta vide što može biti fantastična priča.

Slikanjem prstima, autoagresivnim slikanjem, često može izraziti svoj bijes i druge osjećaje. Hiperaktivno dijete $s$ teškoćama $u$ 
motornoj koordinaciji kad slika prstima, postaje smireno i koncentrirano, premda neka od ove djece ne kompletiraju sliku ali mogu pričati o svome životu, o lošim osjećajima sa samim sobom, o svome bijesu prema roditeljima, učiteljima i sl. Dijete koje slika prstima može mijenjati boje i šare, te ih brzo brisati.

\section{Slikanje stopalima}

Stopala su kod djece vrlo osjetljiva. Djeca mogu slikati svim dijelovima stopala, prstima, petom, stopalima sa strane i pokušavaju uočiti razliku između stopala. Obično izražavaju osjećaje smirenosti i radosti što su uključeni u aktivnosti koja nisu uobičajene, koje predstavljaju privilegiju u školi. Prisjetimo se kako djeca vole tapkati po baricama, te koliko im je zadovoljstvo slikati bosim nogama.

Bez obzira kojom tehnikom radili, osnovni cilj je pomoći djetetu da postane svjesno sebe i svoga postojanja u svome svijetu.

Sugestija za terapeutski proces može biti i ovakva:

- Navodimo dijete da iskaže svoja osjećanja;

- Navodimo dijete da opisuje sliku;

- Tražimo da objasni dijelove crteža oblike, boje, predmete, ljude, odnosno ono što je predstavilo);

- Tražimo da dijete opiše sliku kao da je ono to samo;

- Modeliranje plastelinom ili glinom, prikaz volumena i forme.

\section{Aktivnosti koje potiču kreativnost}

Poteškoće u ponašanju imaju većinom sva djeca kojima roditelji, u važnim stvarima, nisu postavili granice, i koja će djelovati razmaženo, ali će suštinski biti nesigurna pošto nemaju oslonac ni u sredini ni u samima sebi. Takva djeca imaju posebne probleme u emocionalnome razvoju, u teškoćama koje ih prate. U općoj populaciji djece to mogu biti i prolazni problemi koji se $u$ toku, pravilno pedagoški vođenog razvoja, gube.

Postupci navedeni u segmentu okvirnog programa namijenjeni su djeci koja mogu imati problema u razvoju, ali kod kojih se ne može govoriti o pravoj patologiji, kao i kod ostale djece. 
Nastavnik mora imati u vidu činjenicu, da je psihički život djeteta veoma osjetljiva oblast i njome se ne može ovladati samo čitajući literaturu i podižući djecu. Prava kompetencija zahtjeva daleko ozbiljnije procjenjivanje i poznavanje djeteta. Nastavnik, koji treba da duži period prati djecu u jednome odjeljenju, treba predvidjeti i očekivane ishode. U tom pravcu treba iznalaziti postupke za stimulaciju pravilnog razvoja djeteta.

Praćenje razvoja djeteta od strane razrednog nastavnika upotpunjuje sliku psihološke dijagnostike djeteta i pedagoške perspektive, odnosno očekivanih rezultata. To je jedan od najsloženijih zadataka nastavnika u školi. Dijagnostika i pravilan prihvat djece od strane razrednog nastavnika, smanjit će traumu polaska djeteta u školu s kojom se svakodnevno suočavamo, a koja podjednako pogađa i porodicu i dijete. Nastavnik je u najboljoj poziciji da djelovanjem autoriteta prvog učitelja i dobrom procjenom sa mnogo umješnosti, najlakše razriješi postojeće probleme s kojima se dijete svakodnevno neminovno susreće.

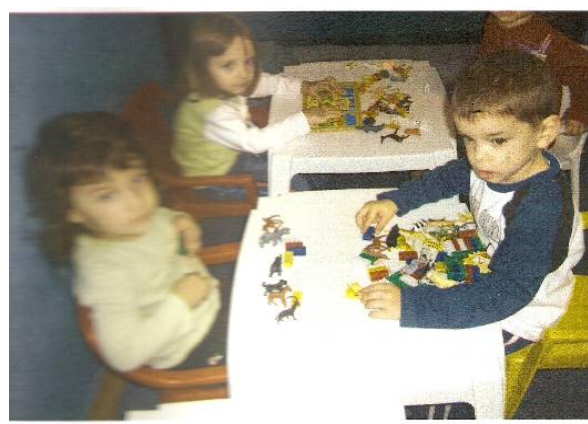

Slika 1. Igra sa kockicama i životinjama

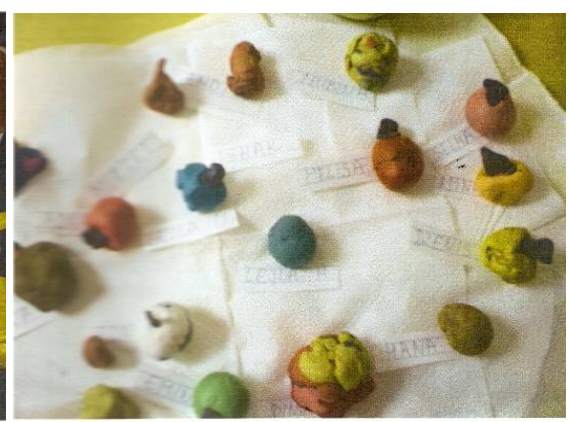

Slika 2. Oblikovanje elemenata od glinamola

\section{Djeca u prvom djetinjstvu}

Djeca uopće, pa i djeca u prvome djetinjstvu (između prve i treće godine života), upijaju svim čulima sasvim nove podatke i sadržaje, te se izražavanje djeteta odvija kroz igru. Igra mu je neophodna. Ona se označava kao sanjarenje na javi. Djeca mijenjaju čas jednu, čas drugu igru. Dječji nemir može se shvatiti kao težnja za iskustvom.

U narodu su sačuvane dječje pjesmice koje kazuju da su nastale iz same igre. One se nalaze u dječjim ritmovima, glasovima, 
pokretima i likovnim otiscima, te dječjim iskustvima iz porodice, gdje dijete prima prve slike svim čulima, posebno čulom vida i dodira.

Dijete se igra sopstvenim tijelom, igračkama, svjetlom i sjenom. Ne zadovoljava se što predmet vidi, već ga analizira, okreće, opipava. Iz želje da ga što bolje upozna, predmet unosi u usta. Zašto?

Poznato je da dijete dolaskom na svijet donese neke instinkte, među kojima i nagon gladi. Tako preko usana dijete prvo upoznaje majčinu dojku. $U$ isto vrijeme djeca nemaju razvijen organ vida koliko organ dodira. Zato su djeca do tri godine više zainteresirana za volumen.

Sljedeće likovno sredstvo je linija. I ona se javlja kao elemenat dječje igre, iako linija u prirodi ne postoji. To je zamišljena crta koju mi vidimo u granama drveća, žicama dalekovoda, bandera itd. Likovni govor izražen linijom nazivamo dječji crtež. Djeca crtaju kroz igru, kad god im se pruži prilika, bilo gdje i bilo čim. Crtaju spontano, držeći olovku čas jednom, čas drugom rukom.

Već u trećoj godini života dijete prvi put pokušava stvarati. Prvi crteži su stvoreni tačkicama i isprekidanim linijama, što im ostavlja crtež vučen nezgrapnom rukom na nekoj ravnoj podlozi. Tako nastaje prvi dječji likovni govor: linijom na podu, zidu, namještaju, zamagljenom prozoru, betonu, pijesku, po bracinim i sekinim sveskama. Dijete se čudi svome radovima, a oni su nastali kao rezultat mehaničkog povlačenja po nekoj gruboj podlozi. Linije su ravne i oble, a crteži se kreću od svijetlih lirskih do tamnih dramskih raspoloženja.

Kao što znamo, dijete $\mathrm{u}$ porodičnome domu dolazi u dodir $\mathrm{s}$ plastičnim predmetima, igračkama ili nekim drugim ukrasnim predmetima, što često izaziva povike i negodovanje roditelja. Dakle,djeca se u prvome djetinjstvu likovno izražavaju na ravnoj podlozi, šaranjem ili škrabanjem koje naginje apstrakciji, za razliku od izražavanja volumenom ili plastikom, što u osnovi izražava životno iskustvo, jer odražava konkretan i opipljiv sadržaj.

Sklonost izražavanja linijom na plohi i volumenom u prostoru je sama potreba koja leži u samom biću čovjeka i djeteta. Dijete te oblike najprije osjeti i upozna, a ruka najlakše likovno realizira. Nisu li ti motivi kod djece prisutni u samoj toplini majčinoga tijela? Po tome 
osjetu i uzoru, djeca te oblike, oble i tople najčešće likovno izražavaju. Okrugle, jajaste forme su forme sunca, ploda, atoma, naše planete, Mjeseca, koje u prostoru prave kružne i elipsaste putanje. Toj strukturi su slični i dječiji crteži.

Da li možda ta činjenica leži u osnovi samoga bića i njegovoga izraza?

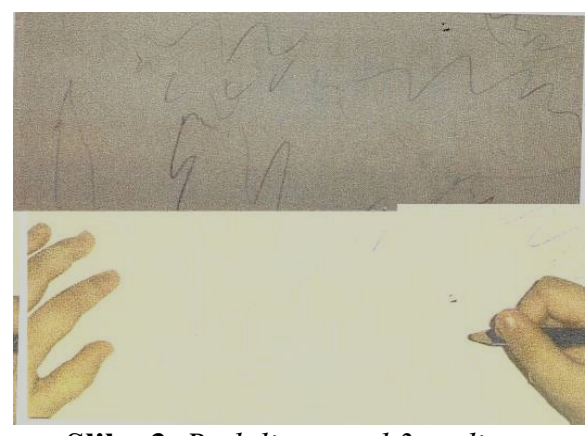

Slika 3. Rad djeteta od 3 godine

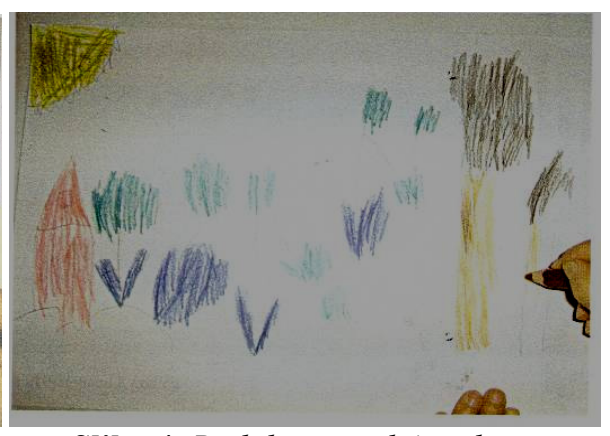

Slika 4. Rad djeteta od 4 godine 


\section{Stvaralačko izražavanje djece}

GRAFIČKI PRIKAZ PRISUTNOSTI TOKA PSIHOFIZIČKIH

FUNKCIJA U CRTAĊKOM IZRAŻAVANJU DJECE

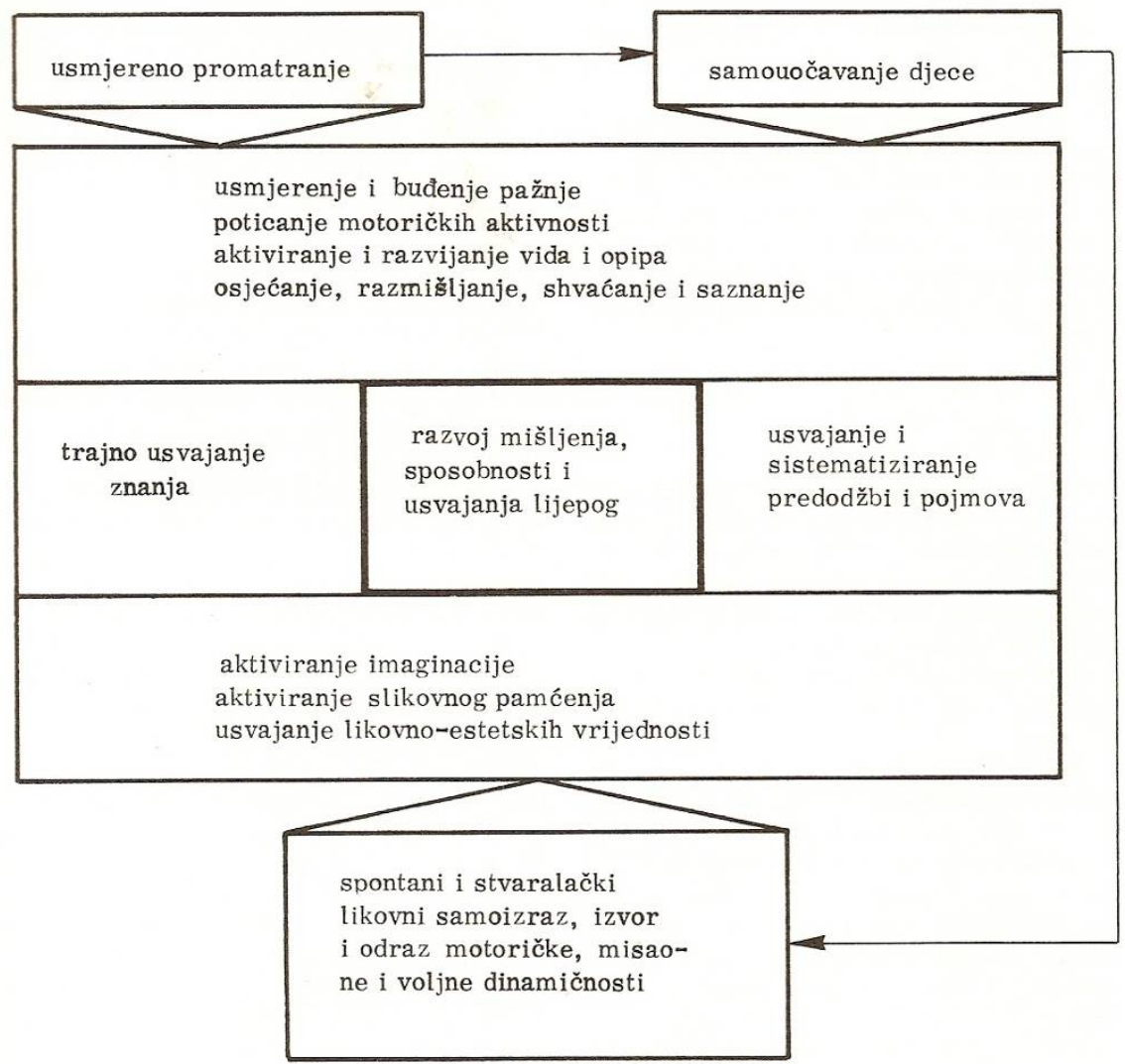

Djeca će se stvaralački izražavati i stvaralački će oblikovati uvijek kad im je dana sloboda da budu ono što jesu, da vide na svoj način, da poimaju i misle svojom logikom. Drugim riječima, da imaju pravo na svoje individualno izražavanje i stvaranje u punome smislu riječi.

Kada djeca prate neku pojavu vanjskog ili unutrašnjeg svijeta, promatraju je njima svojstvenim načinom neposrednog kontakta $\mathrm{i}$ poistovjećivanja $\mathrm{s}$ njom, njihova će interpretacija biti stvaralačka. Pokretač toga je unutrašnji poriv koji se očituje kroz radoznalost i interes djece, ovisno u kojoj mjeri su oni očuvani i u kojoj su mjeri stvoreni osnovni uvjeti za stvaralaštvo. 
Usmjerenost pažnje djeteta koja nadilazi uobičajenu percepciju, možemo nazvati stvaralačkom percepcijom. Tek kada se ona uspostavi, dijete može učiniti sljedeći korak i likovno izraziti svoje doživljaje. Da bi percipirani sadržaji i otkrića sazreli, razvili se, te dublje i trajnije urezali u svijest djece, potrebno je da se oni konkretiziraju i ostvare preko likovnog izraza.

Likovno izraženi i ostvareni sadržaji povratno osnažuju sposobnosti opažanja, predočavanja i shvaćanja djece, a to opet rezultira snažnijim i bogatijim stvaralaštvom. Tako se uspostavlja prirodni proces rasta i razvoja njihove svijesti i sposobnosti.

Postoji nekoliko načina da u djece pobudimo interes za pojave u svijetu te njihovo likovno izražavanje, odnosno oblikovanje:

\section{Usmjeravanje opažanja}

Prvi i najjednostavniji način poticanja djece je usmjeravanje njihova opažanja na neki oblik ili pojavu: na drvo, na kuću, na let, na rast i sl.

Ono što će djecu najviše zaokupiti i zainteresirati bit će život, funkcija i svojstva oblika, zatim, slijedi zanimanje za dijelove oblika, za veličine, za vizualna obilježja, za materijal, boju i detalje. Pošto dijete na taj način upozna i doživi neki oblik ili pojavu, ono će ih lahko i originalno izraziti likovnim medijem. Vrijeme potrebno da dijete nešto percipira i doživi obično je kratko. Ponekad je to samo rezultat intenzivnog interesa i koncentracije. Drugim riječima, djeca ne crtaju ono što konkretno vide, nego ono što doživljavaju, pamte i poimaju;

\section{Aktiviranje sjećanja}

Drugi način pokretanja interesa i likovnog izražavanja djece je i razgovor o nečemu što su djeca spontano vidjela i doživjela prije kraćeg ili dužeg vremena. Sve se to smišljeno postavljenim pitanjima može obnoviti i u vidu slike i pojaviti se u njihovoj svijesti. U likovne radove nastale prema sjećanjima, djeca češće unose značenja i odnose među oblicima, te širinu i cjelovitost događanja, tako da ta dva načina dopunjuju i čine komplementarnu cjelinu; 


\section{Maštanje, ilustracije}

Maštanje se u likovnom izrazu djece najčešće javlja kao stvaranje novih varijanti i slika na osnovu poznatih događaja ili pojava. Bogatstvo i originalnost dječje mašte uvjetovani su slobodnim, spontanim i osmišljenim vođenjem u likovnom izražavanju svega što čini okolinu i život djece. Tada ona imaju od čega stvarati svoje vizije i ideje;

\section{Zamišljanje}

Druga viša razina stvaranja slika ili imaginacije je sposobnost djece da različite predodžbe i pojmove iz sfera nevidljive stvarnosti prenesu u likovni izraz, odnosno u slike i trodimenzionalne oblike;

\section{Potvrđivanje}

Nenametljivo potvrđivanje vrijednosti svakog dječjeg likovnog rada, njegove uspješnosti ili ljepote, djetetu znači orijentaciju ili potvrdu da je na dobrom putu, da je sposobno, da može i da zna. Sve mu to daje osjećaj sigurnosti i slobode. U takvoj atmosferi likovno stvaralaštvo može postati stalni i aktivni dio dječjeg življenja i doživljaja. Kod djece opažajno mišljenje još nije dovoljno razvijeno. Ono se postepeno razvija a tome crtanje može dosta doprinijeti. Praktičan rad obogaćuje oko i misao, ali i oko i misao obogaćuje praktičan rad.

Kad smo uočili prisutnost i važnost psihofizičkih funkcija $u$ likovnom odgoju (likovnoj kulturi) nadasve crtanju djece i omladine, treba naći efikasan put za intenziviranje njihovoga razvoja u nastavi. Osim likovno-estetskih sadržaja koji su glavni sadržaji ovoga područja, treba jednako obratiti pažnju i na motoričko-psihološku suštinu praktičnih aktivnosti, bez kojih nema stvaralaštva. Uz posve slobodan crtež treba dati mjesta poticaju, motivaciji, usmjerenom intenzivnom doživljaju i zadanom motivu.

Dakle, kad nije riječ o posve slobodnom crtanju nego o slučaju kada nastavnik animira djecu za motiv onda treba odrediti i metode crtanja.

Metode crtanja su:

1. crtanje na temelju stvaralačke mašte - imaginacija, 
2. crtanje na temelju slikovnog pamćenja - memorija,

3. crtanje na temelju organiziranog predpromatranja - opservacija, memorija,

4. crtanje na osnovu izravnog promatranja - opservacija,

5. crtanje na temelju literarnog predloška - ilustracija, memorija, imaginacija.

\section{Zaključak}

Likovni odgoj danas predstavlja proces razvijanja sposobnosti djece $u$ pravcu duhovnoga obogaćivanja . Zato se u savremenoj školskoj praksi, posebno u likovnome odgoju, omogućuje učenicima da stvaralački rješavaju zadatke, da u rad unose svoje dječje oduševljenje, uzbuđenje, maštu, shvatanje. Naročito treba istaći veliku odgojnu vrijednost likovnog odgoja, jer je to jedna od rijetkih odgojnih oblasti koja doprinosi stvaranju nove i slobodne stvaralačke ličnosti

Dječiji crtež nam otkriva dijete u svoj njegovoj kompleksnosti, te na taj način možemo upoznati dječji unutrašnji svijet i psihičke aktivnosti. Kao što vidimo umjetnost je danas, pored izlagačke, postala veoma značajna za razvoj dječje ličnosti i njene kreativnosti. Ako se crtanje i slikanje primjeni kao terapijski rad, naći će mjesto $\mathrm{u}$ ergo terapiji i u postupku liječenja uz ostala terapijska sredstva. Tumačenje crteža temelji se na likovnoj analizi istovremenih psiholoških koncepcija. Bolesnički crteži nemaju ništa zajedničkog sa umjetničkim izrazom, ali zato ima umjetnost kao terapija pomoću koje bolesnici izražavaju svoje osjećaje i svoj unutrašnji svijet.

\section{Literatura:}

1. Bodulić Veljko, Umjetnički i dječiji crtež, Školska knjiga, Zagreb, 1982.

2. Djeca sa posebnim potrebama u mlađim razredima osnovne škole, Prijedlog modela Upravnog tijela za pripremu prijedloga strategije prelaska na obavezno devetogodišnje osnovno obrazovanje u Federaciji Bosne i Hercegovine.

3. Fetahagić Branka - Grozda Miluinović, Likovni odgoj za djecu sa posebnim potrebama, Sarajevo.

4. Grgurić - Jakubin, Vizuelno likovni odgoj i obrazovanje, Educa, Zagreb. 
5. Lubovac Ragib, Likovna kultura s metodikom, Sarajevo, 1992-2000.

6. Pražić Branko, Crtež kao prilog u dijagnostici u psihijatriji, Zagreb, 1971.

7. Ružić Branko, Djeca crtaju, Školska knjiga, Zagreb,1959. 


\section{DOC. DR. AHMET IBUKIĆ, SENIOR LECTURER}

\section{ART AS A THERAPY}

\section{SUMMARY}

Children with special needs are for the first time included in the educational process after the school reform and transfer of primary education into nine year period.

Second group consists of children with special needs.

Association of parents, children and youth with special needs as a part of their program activities often organize art workshops - Art therapies, in which children are able to artistically express themselves through game methods in a spontaneous and coincidental way.

Coordination of eye and hand, "sprinkle, sprinkle" technique, spraying and design of colours and shapes, indeed show that children are full of will and imagination.

Emotions and art

Emotions lead us and stimulate the activity. Motivation of the pupils can be accomplished through activation of positive emotions. Emotions, excitement, sensitivity, love and artistic feelings are almost always present in children's artistic creativity.

Absence of positive emotions causes decline in the work intensity of blood flow rhythm and breathing, as a part of endocrine system.

Emotions are often forgotten in teaching. It mostly depends on the teacher and his capability to activate pupils, and sometimes on disposition of pupils.

It is my wish to advert attraction to the significance of art in treatment of mental illnesses and increasing need for affirmation of creativity.

Key words: creativity, art therapy, expression, elements, phenomenology, principle of socialisation, method, education, painting, game, spontaneously, imagination, special, orientation, activation, development 
الأستاذ المساعد أحمد إيبوكيتش

\section{الفن كعلاج}

\section{خلاصة البحث}

مع بداية إصلاح التعليم وانتقال المدرسة الابتدائية من ثماني إلى تسع سنوات ولأول مرة يتم دمج التلاميذ ذوي الاحتياجات الخاصة في العملية التعليمية. "منذ زمن بعيد وقبل أن يكون في التعليم الرسمي فإن مادة الرسم وضعت فيه أهداف تربوية عديدة تشمل النطاق الواسع من

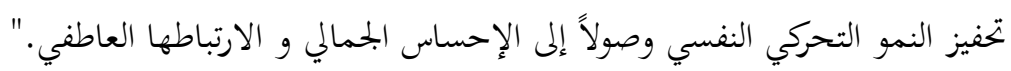

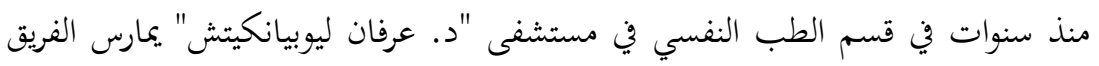
العلاجي نشاطه على شكل العلاج والمصاحبة.

إقامة ورشة العمل الفنية والمعرض تحت عنوان: "بالألوان والكلمات من القلب والروح" يتاح للمرضى أن يصلوا إلى الانتعاش الأسرع من خلال العمل الفني، ويتركون وراءهم

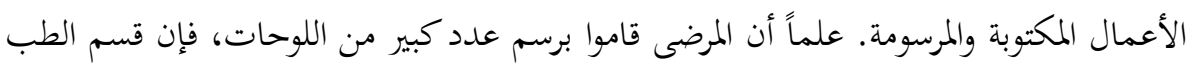
النفسي بالتعاون مع متحف أونسكو سانسكي قام بتنظيم معرض مرضى ورشة عمل علاجية

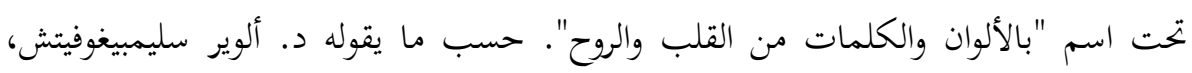
رئيس قسم الطب النفسي، فإن هدف المعرض هو توجه المرضى، بعد عملية علاج مع المختصين والهيئة الطبية إلى البمتمع بهدف دبحهم الأسهل في البحتمع.

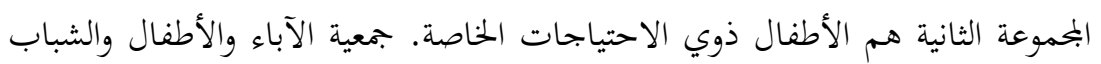
ذوي الإحتياجات الخاصة ضمن برامج نشاطاقم تنظم بشكل متزايد ورشات عمل متعلقة

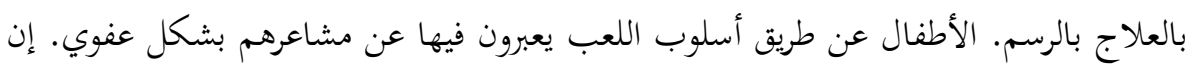
التنسيق بين العين واليد، إضافة إلى الرث وتصميم الألوان والأشكال، يدل على على ألى أن الأطفال مليئون بالرغبة والخيال.

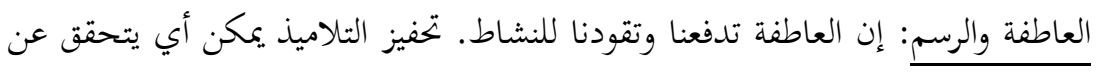

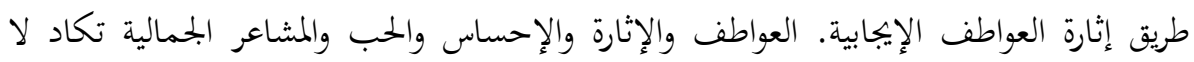
تغيب عن الإبداع في الرسم لدى الأطفال. عدم وجود العواطف الإيجابية يتسبب في الخففاض 
الدورة الدموية والتنفس في نظام الغدد الصماء. إن العواطف كثيراً ما تغفل أهميتها في الدراسة وذلك راجع إلى الأستاذ وقدرته في تنشيط التلاميذ، ويرجع أحياناً إلى مزاج التلاميذ. رغبتي أن ألفت الانتباه على أهمية الفن في علاج الأمراض النفسية والحاجة المتزايدة

لتنشيط الابتكار .

الكلمات الرئيسة: الإبداع، العلاج بالرسم، التعبير، العناصر، الفينومينولوجيا، مبدأ

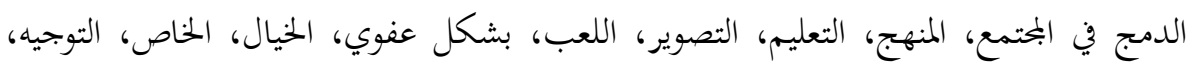
التفعيل، النمو 